\title{
In vitro Organogenesis of Stevia rebaudiana Bert. with Different Explants and Growth Regulators
}

\author{
Aguirre-Medina, Juan Francisco'; Gálvez-López, Ana Laura ${ }^{1}$; Aguirre-Cadena, Juan Francisco ${ }^{1 *}$ \\ ${ }^{1}$ Universidad Autónoma de Chiapas. Facultad de Ciencias Agrícolas. Entronque carretera costera y \\ Estación Huehuetán. CP 30660. Huehuetán, Chiapas, México. \\ *Corresponding author: aguirre.juanf@gmail.com
}

\begin{abstract}
Objective: To evaluate various explants and growth regulators in order to improve in vitro propagation of Stevia rebaudiana through organogenesis.

Design/Methodology/Approach: Explants and growth regulators in two different concentrations were evaluated. The explants were nodal segment, axillary bud, and apical meristem; while the growth regulators were benzylaminopurine (BAP) at $1.125 \mathrm{mg} \mathrm{L}^{-1}$ and $3.0 \mathrm{mg} \mathrm{L}^{-1}$, naphthaleneacetic acid (NAA) at $1.5 \mathrm{mg} \mathrm{L}^{-1}$ and $3.0 \mathrm{mg} \mathrm{L}^{-1}$, and CIDEF-4 brassinosteroids (BRs) at $1.0 \mathrm{mg} \mathrm{L}^{-1}$ and $1.5 \mathrm{mg} \mathrm{L}^{-1}$. In total 18 treatments with seven repetitions. Contamination, oxidation, and survival were recorded during induction; while leaf number, regrowth height, and root presence were recorded during multiplication.

Results: At the induction stage there was a differential response between explants according to their ontogenetic age: during multiplication, the morphological components showed differences between concentrations of growth regulators and explants, with higher effectiveness when adding BAP to apical meristems.

Study Limitations/Implications: Both the origin and the age of explants can induce differential growth while interacting with growth regulators.

Findings/Conclusions: Apical meristem explants showed better advantages for in vitro reproduction of S. rebaudiana since they present less contamination and higher survival at the induction stage, even when exhibiting the highest oxidation among explants, which did not influence the decrease in their survival. At the multiplication stage with apical meristem, height, leaf number, and root presence were increased. Values were high when interacting with BAP.
\end{abstract}

Keywords: stevia, micropropagation, brassinosteroids.

\section{INTRODUCTION}

Stevia rebaudiana rebaudioside A (Oviedo et al., 2015). The leaves of the plant have traditionally been used as a sweetener (Pande and Gupta, 2013). It is non-caloric and sweeter than sucrose or sugar cane (Jagatheeswari and Ranganathan, 2012). The natural sweeteners in S. rebaudiana are appropriate for people who should control the concentration of sugar in their

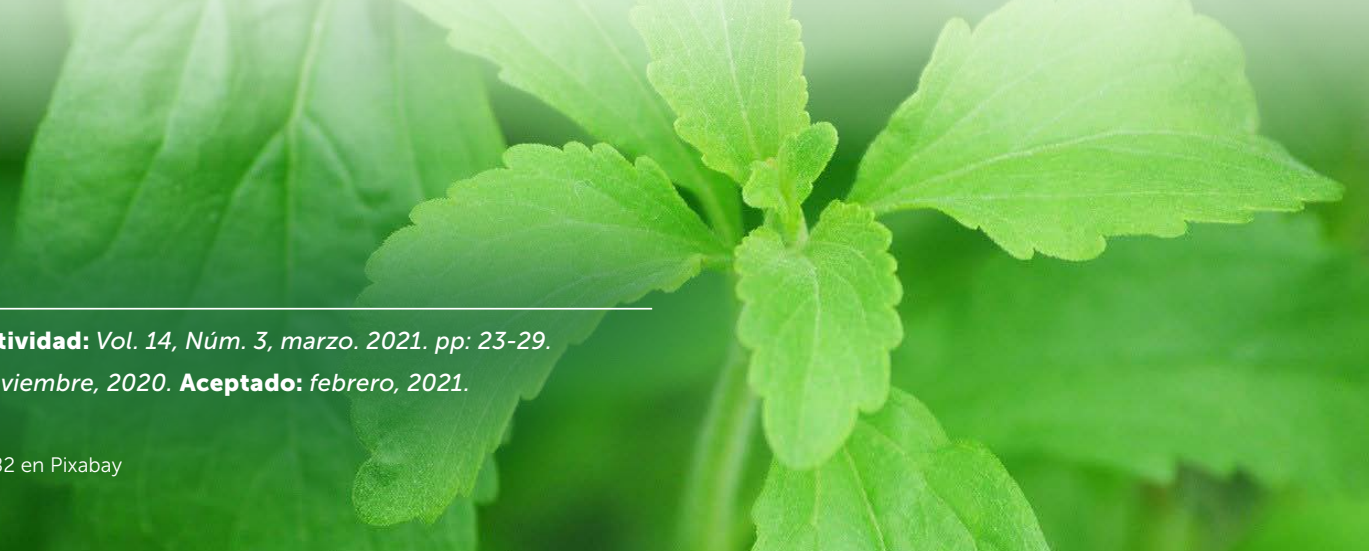


blood (Deshmukh and Ade, 2012; Jagatheeswari and Ranganathan, 2012). In addition, it is non-carcinogenic (Ramya et al., 2014), an attribute distinguishing it from artificial sweeteners. This fact has increased its demand in the national and international markets, and in Mexico an increase in its crop surface has been suggested. It is considered that S. rebaudiana Bert. is likely to have good productivity in the Pacific Slope and some regions of the Gulf of Mexico (Ramírez et al., 2011).

Conventionally, the plant is propagated through cuttings, and this traditional method only allows for the reproduction of few plants. Obtaining the plant via sexual reproduction is also limited due to the scarce seed production of S. rebaudiana and its low percentage of germination (Jagatheeswari and Ranganathan, 2012). Faced with this situation, in vitro reproduction poses an alternative in order to increase multiplication rates (Das, et al., 2011).

Different studies on S. rebaudiana micropropagation have been carried out with various explants, such as leaves (Karimi et al. 2014), internodal segments (Singh et al., 2014), and apexes (Das et al., 2011), and different growth regulators have been tested as well (Singh et al., 2014). However, changes in the cells can be induced with some regulators (Izquierdo et al., 2012), such as cytokinins in high concentrations (Orbovic et al. 2008). Through in vitro reproduction, the absence or concentration of both the medium's compounds and the growth regulators trigger several responses in explant development. Brassinosteroid or homobrassinolide (BR) analogues, which are non-traditional growth regulators, can be used as substitutes for auxins and cytokinins in biotechnological processes (Izquierdo et al., 2012). These are metabolites that are capable of stimulating plant growth through cell division and elongation of shoots and roots (Sirhindi et al., 2011; Vleesschauwer et al., 2012) in segments of different organs and explants (Salgado et al., 2008). In addition, their application positively influences against biotic and abiotic stress during development of the plants (Bajguz, 2010). With that aim, various explants and growth regulators were evaluated in other to improve in vitro propagation of Stevia rebaudiana through organogenesis.

\section{MATERIALS AND METHODS}

The experiment was carried out at the Biotechnology Laboratory of the School of Agricultural Sciences, Campus IV, at the Autonomous University of Chiapas
(Universidad Autónoma de Chiapas, UNACH), located in the municipality of Huehuetán, Chiapas (15 $05^{\circ} 25.02^{\prime \prime}$ $\mathrm{N}$ and $92^{\circ} 23^{\prime} 59.06^{\prime \prime} \mathrm{W}$, at 44 meters in altitude). Two stages were considered: the first was induction, 11 weeks in duration, the second multiplication, which lasted for 17 weeks.

Biological material was obtained from S. rebaudiana var. Morita 2 established in the greenhouse of the Experimental Field at the School of Agricultural Sciences (UNACH). The explants -axillary bud, apical meristem, and nodal segment- were obtained after a two-month growth period. At the greenhouse, the plant was sprayed with Amistar ${ }^{\circledR}$ (azoxystrobin $1.5 \mathrm{~g}$ $\mathrm{L}^{-1}$ ) fungicide during three days before getting the explants. Once removed from the plant, the explants were taken to the laboratory and washed with soap and water. Then, they were kept in agitation for 10 minutes in an azoxystrobin $\left(1.5 \mathrm{~g} \mathrm{~L}^{-1}\right)$ solution, to which a drop of Tween ${ }^{\circledR} 20$ (polyoxyethylene sorbitan monolaurate) was added; likewise, sodium hypochlorite ( $\mathrm{NaClO}$ ) solution at $2.0 \%$ was added for 15 minutes in the laminar flow chamber. Subsequently, the explants were rinsed three times with sterile distilled water and $1.5 \mathrm{~cm}$-long nodal segments, axillary buds between 2.0 and $3.0 \mathrm{~mm}$ in diameter, and $1.5 \mathrm{~cm}$-long apical meristems were obtained from the plants' branches. Before planting, the explants were placed in an antioxidant solution, composed of citric acid $(0.1 \mathrm{~g})$, ascorbic acid $(0.15 \mathrm{~g})$, and sucrose (30 g).

The Yasuda et al. (1985) semisolid medium was employed, modified by adding vitamins and the following growth regulators: BAP (6-benzylaminopurine), NAA (naphthaleneacetic acid) and $\mathrm{Br}$ (brassinosteroid), each one in two different concentrations. Brassinosteroid (BR) CIDEF-4 is a homobrassinolide, produced in Mexico by the Natura del Desierto, S.A. de C.V., company which has $80 \%$ steroidal content and $10 \%$ active with a non-toxic soluble form presentation, compatible with fertilizers, insecticides, and fungicides. The medium was sterilized by autoclave at 15 PSI and $120{ }^{\circ} \mathrm{C}$ for 20 minutes.

The explants were placed in test tubes with $10 \mathrm{~mL}$ medium. Once the planting was carried out in each treatment, they were placed in the incubation room at temperature of $26 \pm 1{ }^{\circ} \mathrm{C}, 60 \%$ relative humidity, and 45 $\mathrm{mE} \mathrm{m}^{2} \mathrm{~s}^{-1}$ light intensity for a period of $16 \mathrm{~h}$ of darkness and $8 \mathrm{~h}$ of light. 
The treatments were generated with the combination of these factors: a) explants (nodal segments, axillary buds, and apical meristems), and b) growth regulators in two concentrations: BAP (1.125 $\mathrm{mg} \mathrm{L}^{-1}$ and $3 \mathrm{mg} \mathrm{L}^{-1}$ ), NAA (1.5 $\mathrm{mg} \mathrm{L}^{-1}$ and $3 \mathrm{mg} \mathrm{L}^{-1}$ ), and BR ( $1 \mathrm{mg} \mathrm{L}^{-1}$ and $\left.1.5 \mathrm{mg} \mathrm{L}^{-1}\right)$. The complete factorial $(3 \times 3 \times 2)$ produced 18 treatments with seven repetitions, distributed in a completely random experimental design. Each explant represented one experimental unit.

After evaluating the induction stage, regrowths from the explants were transplanted for their multiplication and activated carbon ( $1 \mathrm{~g}$ ) was added to the cultivation medium in order to stimulate rhyzogenesis, and medium changes were carried out every 20 days.

The response variables during the induction stage resulted from the average of contamination, oxidation, and survival percentages, evaluated each week. At the multiplication stage, regrowth height, leaf number in each regrowth, and percentage of roots were evaluated. The mean results of the variables from the induction stage were graphed using Sigma Plot (V. 11.0) software by Jandel Scientific. Data of the variables from the multiplication stage were analyzed with SAS for Windows Ver. 8.1 (1999-2000) software, and the means comparison between treatments was performed with Tukey's test $(P \leq 0.05)$. explants, which have older ontogenetic ages, when interacting with growth regulators. With regards to NAA application, a contracting effect was present in contamination; that is, contamination increased in nodal segments with the highest concentration $13.0 \mathrm{mg}$ $\mathrm{L}^{-1}$ ), while an increase in contamination occurred in axillary buds with the lowest dose $\left(1.5 \mathrm{mg} \mathrm{L}^{-1}\right)$. When adding BAP to the cultivation medium, contamination increased in both nodal segments and axillary buds with the lowest dose (1.125 $\mathrm{mg} \mathrm{L}^{-1}$ ). When using $\mathrm{Br}$ in the medium, no differences in contamination figures of axillary buds were detected in the two concentrations evaluated; however, contamination was higher with the highest doses in both nodal segment and apical meristem explants (Figure 1).

The increase in contamination in explants that are older is described by López-Gómez et al. (2010) in Coffea spp. leaves, while Martínez et al. (2016) add that explants do not always respond to the procedures employed in the initial decontamination of the material, especially fungi and bacteria. It is worth mentioning that some plants have various particular morphological attributes that hinder the elimination of contaminants, such as presence of epicuticular waxes, and increase in trichome type, form, and density; or else when a plant is exposed longer to the environment, favoring fungal invasion of the stomatic complex.

\section{RESULTS AND DISCUSSION Induction Stage; Contamination, Oxidation and Survival}

The explants showed lower survival percentages as medium contamination increased. During week 11 of evaluation, average contamination was $65 \%$ in nodal segments, $27 \%$ in axillary buds, and $20 \%$ in apical meristems (Figure 1). In general, contamination in apical meristems decreased when interacting with the lowest doses of all growth regulators. When adding the lowest concentration of NAA (1.5 mg L $\left.{ }^{-1}\right)$ to the medium, the same explant did not show contamination, but when concentration increased to $3.0 \mathrm{mg} \mathrm{L}^{-1}, 10 \%$ showed contamination (Figure 1).

Higher contamination was recorded in nodal segment and axillary bud

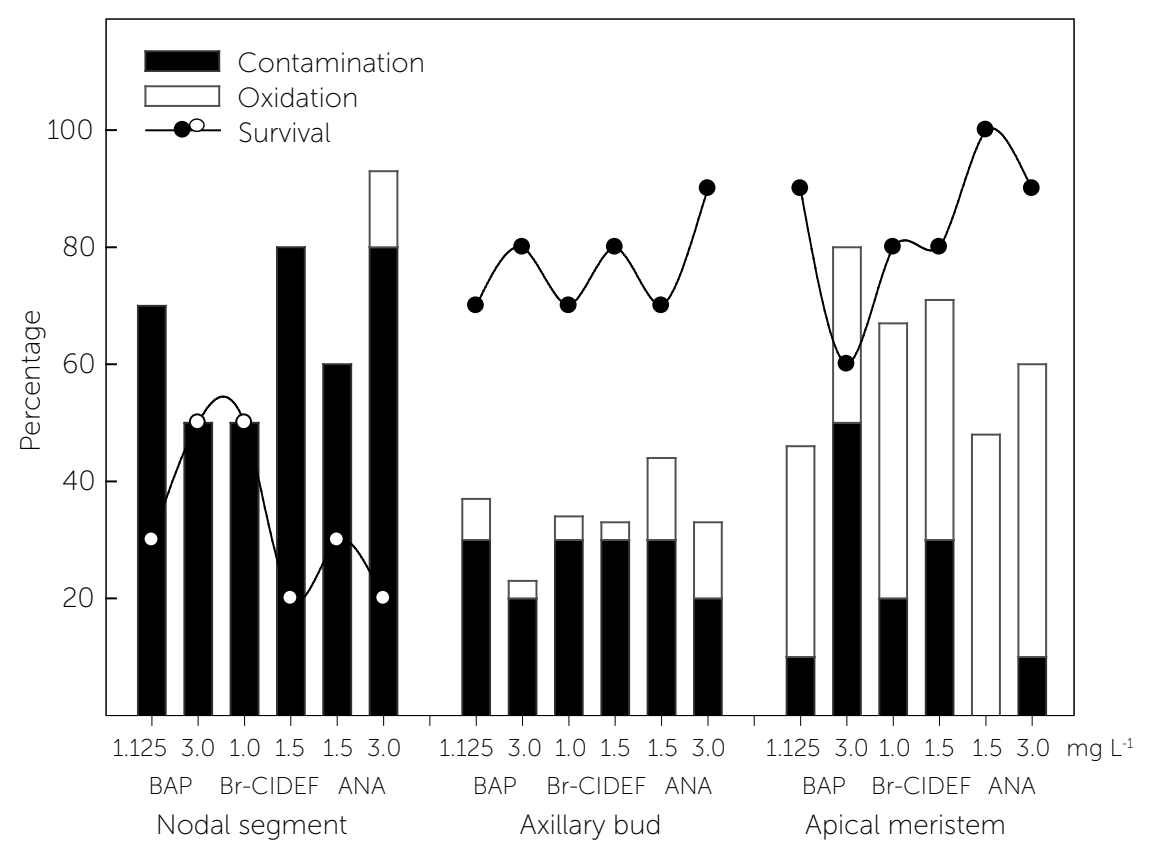

Figure 1. Contamination, Oxidation and Survival of Stevia rebaudiana explants in Yasuda medium with different concentrations of growth regulators. Values are average of seven repetitions. 
Concerning oxidation or tissue darkening, it seems to be more closely related to the explant's age. Apical meristem, which is the young tissue, showed the highest oxidation average (42\%), and decreased to $7 \%$ in axillary buds and to $2 \%$ in nodal segments, which are older tissues. The increase in oxidation in apical meristem was found when NAA was added to the medium. In this regard, the increase in oxidation of young tissue can be caused by the tissue's oxidative stress, resulting from deficiencies in antioxidant defenses (Turrens, 2003), or else by the presence of phenols in the tissues as a result of their reactions to polyphenol oxidases (Scherer et al. 2006), which are exuded into the medium through wounds in the tissue. This problem tends to stop or decrease when the explant starts growing, as was observed in Gossypium hirsutum L (Ozyigit et al. 2007). Oxidation in some species has resolved using polyvinylpyrrolidone (PVP) (Méndez-Alvarez and Abdelnour-Esquivel, 2014). However, Aguirre-Medina et al. (2018) used PVP combined with growth regulators, such as BAP, $N A A$, and IAA, in $S$. rebaudiana explants of leaves, longitudinally cut stems, and apical meristem, and they indicate that there was no influence in the percentages for oxidation averages.

Among explants, the highest survival of seedlings with different concentrations of growth regulators was observed in apical meristem (82\%) and axillary bud (75\%), while the lowest survival corresponds to the nodal segment (33\%). In Heliconia bihai (L.) cv. Lobster Salmón, Marulanda-Angel et al. (2011) account for lower survival on the basis of floral meristems treated with BAP $(2 \mathrm{mg}$ $L^{-1}$ ). In our case, survival was high in apical meristem with $1.25 \mathrm{mg} \mathrm{L}^{-1}$ concentration, and it decreased in axillary bud and nodal segments when increasing concentration to $3.0 \mathrm{mg} \mathrm{L}^{-1}$.

\section{Mutiplication Stage: Regrowth Height and Leaf Number}

The higher average increase in regrowth height among the explants was found in apical meristems $(2.26 \mathrm{~cm})$, and it amounted to 10 and $36 \%$ more growth in relation to nodal segments and axillary buds. Apical meristems (3.45) also presented the highest number of leaves per regrowth on average, and it amounted to 22 and $66 \%$ more leaves when compared to nodal segments and axillary buds. Likewise, it was statistically different (Ps0.05) (Table 1).
The regrowth height and the leaf number in explants with growth regulators showed the highest increase when adding BAP in the highest concentration (3.0 $m g L^{-1}$ ) and were also statistically different ( $\left.P \leq 0.05\right)$ from other regulator concentrations. In this respect, Hassanem and Khalil (2013) mention the same response when applying higher concentrations of BAP, but to MS medium. On the contrary, lower height appeared with $\mathrm{Br}$ at a $1.5 \mathrm{mg} \mathrm{L}^{-1}$ concentration, and represented 5\% less when compared to a $\mathrm{Br}$ concentration of $1.0 \mathrm{mg}$ $L^{-1}$, although the leaf number increased by $4 \%$ with the highest $\mathrm{Br}$ concentration when compared to the lowest one (Table 1). This outcome is probably linked to its increase in the plant's apexes. The $\mathrm{Br}$ is not subjected to active transport inside the plant (Hategan et al., 2013), since its metabolism interacts with different enzymes in the cell's organelles and is capable of exhibiting one of the many physiological activities of $\mathrm{Br}$, such as cell division and elongation (Sirhindi, 2013). Induction in plant growth depends on $\mathrm{Br}$ concentration, treatment duration, and age when the treatment was introduced, as happened when applying different concentrations of 24-epibrassinolide and 28-homoethylcastasterone to Vigna irradian L. and Brassica juncea L., which improved photosynthetic rate, total chlorophyll, chlorophylls a and b, carotenoids, shoot length, and fresh and dry weight (Fariduddin et al., 2011; Sirhindi et al., 2011).

Regarding the interaction between concentrations of growth regulator and explants, the greatest increase in height occurred for apical meristems and nodal

\begin{tabular}{|c|c|c|}
\hline Explant & $\begin{array}{l}\text { Height }(\mathrm{cm} \\
\left.\text { regrowth }^{-1}\right)\end{array}$ & $\begin{array}{c}\text { Number of leaves } \\
\text { regrowth }^{-1}\end{array}$ \\
\hline Nodal segment & $2.03 b^{*}$ & $2.66 \mathrm{~b}$ \\
\hline Apical meristem & $2.26 \mathrm{a}$ & 3.45 a \\
\hline Axillary bud & $1.43 \mathrm{c}$ & $1.14 \mathrm{c}$ \\
\hline \multicolumn{3}{|c|}{ Growth regulators $\left(\mathrm{mgL}^{-1}\right)$} \\
\hline BAP 1.125 & $1.91 \mathrm{c}$ & $2.71 \mathrm{~b}$ \\
\hline BAP 3.0 & $2.01 \mathrm{a}$ & $3.14 \mathrm{a}$ \\
\hline $\operatorname{Br} 1.0$ & $1.86 \mathrm{e}$ & $2.42 \mathrm{~d}$ \\
\hline $\operatorname{Br} 1.5$ & $1.77 \mathrm{f}$ & $2.52 \mathrm{c}$ \\
\hline ANA 1.5 & $1.98 \mathrm{~b}$ & $1.42 \mathrm{f}$ \\
\hline ANA 3.0 & $1.91 \mathrm{~d}$ & $2.28 \mathrm{e}$ \\
\hline
\end{tabular}

*Different letter values, within columns and factor, are statistically different (Tukey, $\mathrm{p}$ 50.05). BAP (6-benzyl amino purine), $\mathrm{Br}$ (Brassinosteroid), ANA (Naphthaleneacetic Acid). 
segments. The first increased with the two concentrations of NAA, plus BAP at $3.0\left(\mathrm{mg} \mathrm{L}^{-1}\right)$, and in nodal segments all treatments were included within the first statistical group.

With regards to the interaction of both factors, explants and growth regulators, the number of leaves per regrowth increased by 5.0 in apical meristems and the lowest BAP dose (1.125 $\mathrm{mg} \mathrm{L}^{-1}$ ), and was statistically superior to the rest of the treatments $(P \leq 0.05)$, followed by the induction of 4.4 leaves with BAP at $3.0 \mathrm{mg} \mathrm{L}^{-1}$ (Table 2). This result agrees with what was reported by Jagatheeswari and Ranganathan (2012), who mention that high BAP doses delay growth in S. rebaudiana. Other authors recount similar results when adding BAP to MS medium in the same species (Khalil et al., 2014; Jagatheeswari and Ranganathan, 2012).

The highest leaf number per regrowth (5.0) was achieved in epical meristems interacting with BAP at $1.125 \mathrm{mg} \mathrm{L}^{-1}$, and in nodal segments (4.0) with inclusion of BAP. In this respect, the addition of BAP to MS medium has conveyed this same result in Stevia (Abd-Alhady, 2011; Rangappa and Aind, 2013). In relation to concentrations, there is evidence that adding $3.0 \mathrm{mg} \mathrm{L}^{-1}$ fosters regrowth (Abd-Alhady, 2011; Fatima and Khan, 2011; Hassanen and Khalil, 2013), but also the $1.0 \mathrm{mg} \mathrm{L}^{-1}$ dose (Thiyagarajan and Venkatachalam, 2012) in MS medium. Intermediate values of 2.7 leaves per regrowth were obtained with $\mathrm{Br}$ in nodal segments. $\mathrm{Br}$ (28-homoethylcastasterone) was applied to Mallus prunifolia (Willd.) Borkh. apex, which increased the number of shoots when benzyladenine was added to the medium (Schaefer, 2002).

In axillary buds, BAP and NAA induced lower regrowth, one regrowth on average, and just two regrowths when adding $\mathrm{Br}$ in its lowest concentration (1.0 mg L1). Other authors have combined BAP and naphthaleneacetic acid (in a 2 to 1 proportion) in Stevia axillary bud and MS medium, in order to increase the number of regrowths (Rangappa and Aind, 2013). In other results for nodal segment and axillary bud, it was found that there was better regrowth induction when adding low concentrations, BAP from 1.0 to $1.5 \mathrm{mg} \mathrm{L}^{-1}$ plus kinetin in more than $0.5 \mathrm{mg} \mathrm{L}^{-1}$, to MS medium (Aamir et al., 2010; Fatima and Khan, 2011). On the contrary, Khalil et al. (2014) indicate that adding 2,4-D to the medium, in combination with BAP and NAA or indolebutyric acid, on its own or combined with NAA, significantly inhibits the number of stems per explant in S. rebaudiana.

The presence of roots was apparent in the apical meristem explant while interacting with the three growth regulators added to the medium. This result suggests the importance of both the explant and its age in order to favor organ development in plants under in vitro conditions. Several authors report greater radical growth when applying NAA to S. rebaudiana explants (Shatnawi et al., 2011; Sikdar et al., 2012).

\section{CONCLUSIONS}

The apical meristem explant shows better advantages for in vitro reproduction of Stevia rebaudiana given that it shows less contamination and higher survival at the induction stage. Even when it did show the highest

Table 2. Morphological components in explants of Stevia rebaudiana Bert. in interaction with different concentrations of growth regulators during the multiplication stage.

\begin{tabular}{ll|l} 
Explant & Treatment & Height $(\mathrm{cm}$
\end{tabular}

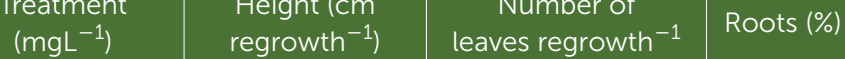

\begin{tabular}{|c|c|c|c|c|}
\hline \multirow{6}{*}{ Nodal Segment } & BAP 1.125 & $1.80 \mathrm{bcde}^{*}$ & $2.28 \mathrm{de}$ & 20 \\
\hline & BAP 3.0 & $2.21 \mathrm{ab}$ & $4.00 \mathrm{bc}$ & 0 \\
\hline & $\mathrm{Br} 1.0$ & $2.11 \mathrm{abc}$ & $2.71 \mathrm{de}$ & 0 \\
\hline & $\mathrm{Br} 1.5$ & $1.42 \mathrm{de}$ & $2.71 \mathrm{de}$ & 10 \\
\hline & ANA 1.5 & $2.42 \mathrm{a}$ & $1.14 \mathrm{fg}$ & 0 \\
\hline & ANA 3.0 & $2.21 a b$ & $3.14 \mathrm{~cd}$ & 0 \\
\hline \multirow{6}{*}{ Axillary bud } & BAP 1.125 & $1.50 \mathrm{cde}$ & $1.00 \mathrm{~g}$ & 0 \\
\hline & BAP 3.0 & $1.44 \mathrm{de}$ & $1.00 \mathrm{~g}$ & 0 \\
\hline & $\mathrm{Br} 1.0$ & 1.54 cde & 2.00 ef & 0 \\
\hline & $\operatorname{Br} 1.5$ & $1.50 \mathrm{cde}$ & $1.00 \mathrm{~g}$ & 0 \\
\hline & ANA 1.5 & $1.34 \mathrm{de}$ & $1.00 \mathrm{~g}$ & 0 \\
\hline & ANA 3.0 & $1.25 \mathrm{e}$ & $1.00 \mathrm{~g}$ & 0 \\
\hline \multirow{6}{*}{ Apical meristem } & BAP 1.125 & $2.45 a$ & $5.00 \mathrm{a}$ & 20 \\
\hline & BAP 3.0 & $2.31 \mathrm{ab}$ & $4.42 \mathrm{ab}$ & 20 \\
\hline & Br 1.0 & $1.92 \mathrm{abcd}$ & $2.57 \mathrm{de}$ & 20 \\
\hline & $\mathrm{Br} 1.5$ & $2.40 a b$ & $3.85 b c$ & 10 \\
\hline & ANA 1.5 & $2.18 a b$ & $2.14 \mathrm{e}$ & 20 \\
\hline & ANA 3.0 & $2.25 a b$ & $2.71 \mathrm{de}$ & 10 \\
\hline
\end{tabular}

* Different letter values, within columns and factor, are statistically different (Tukey, $\mathrm{p} \leq 0.05$ ). BAP (6-benzyl amino purine), Br (Brassinosteroid), ANA (Naphthaleneacetic Acid). 
oxidation among explants, this did not influence on the decrease of their survival. Height, leaf number, and root presence were increased at the multiplication stage with apical meristem. Values were outstanding when interacting with BAP.

\section{REFERENCES}

Aamir, A., Irum, G.l., Shagufta. N., Shahid. A. 2010. Biochemical investigation during different stages of in vitro propagation of Stevia rebaudiana. Pakistan Journal of Botany 42(4): 28272837.

Abd-Alhady, M.R.A. 2011. Micropropagation of Stevia rebaudiana Bertoni. A New Sweetening Crop in Egypt. Global Journal of Biotechnology and Biochemistry 6 (4): 178-182.

Aguirre-Medina, J.F., Gálvez López, A.L., De León, R.J.M. y Rodas Miguel, N. 2018. Explantes para la obtención de callos embriogénicos somáticos en Stevia rebaudiana (Bert.). In Alimentación sostenible y retos del sistema agroalimentario. Imelda Rosana Cih Dzul, Arturo Moreno Hernández, Francisco Javier Cárdenas Flores, Víctor Manuel Sánchez Bernal, Cándido Enrique Guerra Medina (Eds). Primera Edición. Editorial Página Seis, S.A. de C.V. Teotihuacan 345, Ciudad del Sol, C.P. 45050, Zapopan, Jalisco. Pp 457-476.

Bajguz, A. 2010. An enhancing effect of exogenous brassinolide on the growth and antioxidant activity in Chlorella vulgaris cultures under heavy metals stress. Environ Experimental Botany 68:175-179

Das, A., Gantait, S., Mandal, N. 2011. Micropropagation of an Elite Medicinal Plant: Stevia rebaudiana Bert. International Journal of Agricultural Research 6: 40-48. doi: 10.3923/ijar.2011.40.48

Deshmukh, S., Ade, R. 2012. In vitro rapid multiplication of Stevia rebaudiana: an important natural sweetener herb. Nusantara Bioscience 4(3): 105-108.

Fatima, A., Khan, S.J. 2011. Some factors affecting the in vitro growth of Stevia rebaudiana Bertoni. Iranian Journal of Plant Physiology 1 (2): $61-68$

Fariduddin, Q., Yusuf, M., Chalkoo, S., Hayat, S., Ahmad, A. 2011 28-Homobrassinolide improves growth and photosynthesis in Cucumis sativus L. through an enhanced antioxidant system in the presence of chilling stress. Photosynthetica 49(1):55-64

Hassanen, S.A., Khalil, R.M.A. 2013. Biotechnological Studies for Improving of Stevia (Stevia rebaudiana Bertoni) in vitro Plantlets. Middle-East Journal of Scientific Research 14 (1): 93-106.

Hategan, L., Godza, B., Szekeres, M. 2010. Regulation of brassinosteroid metabolism. In: Hayat S, Ahmad A, editors, Brassinosteroids A Class of Plant Hormone, Springer, Dordrecht, 5781. doi:10.1007/978-94-007-0189-2_3

Izquierdo, H., González, M.C., Núñez, M., Proenza, R., Álvarez, I. 2012. Efectos de la aplicación de un análogo espirostánico de brasinoesteroides en vitroplantas de banano (Musa spp.) durante la fase de aclimatización. Cultivos Tropicales 33(1) 71-76.

Jagatheeswari, D., Ranganathan, P. 2012. Studies on Micropropagation of Stevia rebaudiana Bert. International Journal of Pharmaceutical and Biological Archive 3(2): 315-320.

Khalil, S.A., Zamir, R., Ahmad, N. 2014. Selection of suitable propagation method for consistent plantlets production in Stevia rebaudiana
(Bertoni). Saudi Journal of Biological Sciences, 21 (6), 566-573 doi:10.1016/j.sjbs.2014.02.005

Karimi, M., Ahmadi, A., Hashemi, J., Abbasi, A., Angelini, L.G. 2014. Effect of two plant growth retardants on steviol glycosides content and antioxidant capacity in Stevia (Stevia rebaudiana Bertoni). Acta Physiologiae Plantarum 36(5): 1211-1219; doi: 10.1007/ s11738-014-1498-8

López-Gómez, P., Iracheta-Donjuan, L., Castellanos-Juárez, M. Méndez-López, I., Sandoval-Esquivez, A., Aguirre-Medina, J.F., Ojeda-Zacarías, M.A., Gutiérrez-Díez, A. 2010. Influencia de explantes y medio de cultivo en la embriogénesis somática en hojas de café. Revista Fitotecnia Mexicana 33(3): 205-213.

Martínez Rivillas, D., Urrea, A., Jiménez, E., Atehortua, L. 2016. Estrategia para la propagación in vitro de Stevia rebaudiana Bertoni. Biotecnología Vegetal 16 (3): 131-142.

Marulanda-Ángel, M.L., Isaza-Valencia, L., Londoño-Giraldo, L.M. 2011. Propagación in vitro de Heliconia bihai (L.) cv. Lobster Salmón a partir de meristemos florales. Acta Agronómica, 60 (2): 132-139

Méndez-Álvarez, D., Abdelnour-Esquivel, A. 2014. Establecimiento in vitro de Terminalia amazonia (Gmel.) Excell. Revista Forestal Mesoamericana Kurú (Costa Rica), 11(27):7-21.

Murashige, T., Skoog, F. 1962. A revised medium for rapid growth and bioassays with tobacco tissue cultures. Physiologia Plantarum 15 (3): 437-497

Oviedo, P.D., Alvarenga, V.S., Evangelista, L.S., Sepúlveda, J.G., Rodríguez, M.M. 2015. Micropropagación de Stevia rebaudiana Bertoni, un Cultivo Promisorio para México. BioTecnología 19(2): 14-27.

Orbovic, V., Calovic, M., Viloria, Z., Nielsen, B., Gmitter, F.G. Jr, Castle, W.S., Grosser, J.W. 2008. Analysis of genetic variability in various tissue culture-derived lemon plant populations using RAPD and flow cytometry. Euphytica. 161 (3): 329-335. doi:10.1007/ s10681-007-9559-3

Ozyigit, I., Kahraman, M., Ercan, O. 2007. Relation between explant age, total phenols and regeneration response in tissue cultured cotton (Gossypium hirsutum L.). African Journal of Biotechnology 6: 3-8.

Pande, S.S., Gupta, P. 2013. Plant tissue culture of Stevia rebaudiana (Bertoni): A review. Journal of Pharmacognosy Phytother 5(1): 26-33. doi: 10.5897/JPP13. 0258

Ramírez, J.G., Avilés, B.W.I., Moguel, O.Y.B., Góngora, G.S.F., May, L.C. 2011. Estevia (Estevia rebaudiana, Bertoni), un cultivo con potencial productivo en México. Folleto Técnico XX (4⿳亠口了 ed.). Instituto Nacional de Investigaciones Forestales Agricolas y Pecuarias México

Ramya, M., Manogaran, S., Joey, K., Wooi keong, T., Katherasan, S. 2014. Studies on biochemical and medicinal properties of Stevia rebaudiana grown in vitro. International Journal of Research in Ayurveda and Pharmacy 5(2): 169-174. doi: 10.7897 12277-4343.05234

Rangappa, K., Aind, D.S. 2013. High frequency multiplication of shoots using axillary buds for production of elite lines of Stevia rebaudiana. Advances in Bioscience and Biotechnology 4:781784; doi: 10.4236/abb.2013.47102

Salgado, G.R., Cortés Rodríguez, M.A., Del Río, R.E. 2008. Uso de brasinoesteroides y sus análogos en la agricultura. Biológicas 10: $18-27$. 
SAS (Statistical Analysis System). 1999-2000. SAS/STAT user's Guide: Ver 8.1 SAS Institute Inc. Cary NC, USA: SAS Institute Inc.

Schaefer, S., Medeiro, S.A., Ramírez, J.A., Galagovsky, L.R., Pereira-Netto, A.B. 2002. Brassinosteroid-driven enhancement of the in vitro multiplication rate for the marubakaido apple rootstock Malus prunifolia (Willd.) Borkh. Plant Cell Reports 20 (11): 1093-1097.

Scherer, J., Silveira, L., Gomes, B., Peiche, C., Vasconcelos, A. 2006. Oxidação fenólica, tipo de explante e meios de cultura no estabelecimento in vitro de canafístula (Peltophorum dubium (SPRENG.). Ciência Florestal, Santa Maria, 16(4), 381-390. doi: 10.5902 / 198050981919

Shatnawi, M.A., Shibli, R.A., Abu-Romman, S.M., Al-Mazra'awi, M.S., Al Ajlouni, Z.I., Shatanawi, W.A., Odeh, W.H. 2011. Clonal propagation and cryogenic storage of the medicinal plant Stevia rebaudiana. Spanish Journal of Agricultural Research 9(1): 213-220.

Sikdar, S.U., Zobayer, N., Azim, F., Ashrafuzzaman, M., Prodhan, S.H. 2012. An efficient callus initiation and direct regeneration of Stevia rebaudiana. African Journal of Biotechnology 11(45): 10381-10387.

Singh, P., Dwivedi, P., Atri, N. 2014. In vitro shoot multiplication of Stevia and assessment of stevioside content and genetic fidelity of the regenerants. Sugar Tech 16(4):430-439. doi: 10.1007/s12355-013-0292-z

Sirhindi, G., Kumar, M., Bhardwaj, R., Kumar, S., Pradhan, S.K. 2011. Effect of 24-epibrassinolide on activity of antioxidant enzymes in Brassica juncea L. under $\mathrm{H}_{2} \mathrm{O}_{2}$ stress. Indian J Plant Physiology 16(1):68-71. doi: 10.1007 / s12298-009-0038-2

Sirhindi, G. 2013. Brassinosteroids: Biosynthesis and role in growth, development, and thermotolerance responses. Molecular Stress Physiology of Plants, 309-329. doi:10.1007/978-81-322-0807-5_13

Thiyagarajan, M., Venkatachalam, P. 2012. Large scale in vitro propagation of Stevia rebaudiana (Bert) for commercial application: Pharmaceutically important and antidiabetic medicinal herb. Industrial Crops and Products 37(1):111-117. doi:10.1016/j.indcrop.2011.10.037

Turrens, J. 2003. Mitochondrial formation of reactive oxygen species. The Journal of physiology 552: 335-344.

Vleesschauwer, D.D., Buyten, E.V., Satoh, K., Balidion, J., Mauleon, R., Choi, I.R., Vrea-Cruz, C., Kikuchi, S., Hofte, M. 2012. Brassinosteroids antagonize gibberellin and salicylate - mediated root immunity in rice. Plant Physiology 158:1833-1846. doi:10.1104/pp.112.193672

Yasuda, T., Fujii, Y., Yamaguchi, T. 1985. Embryogenic callus induction from Coffea arabica leaf explants by benzyladenine. Plant Cell Physiology 26:

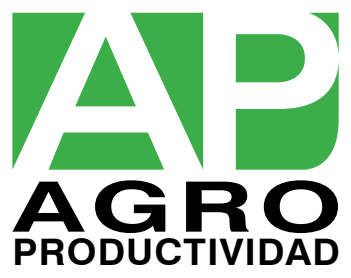

